from any central point down to an equatorial line, and then forced upward by internal pressure.

"I know not what other observers may have written as to the formation of the earliest tentacles in marine medusa; but all our night watchers unhesitatingly agreed that my impressions of ten years ago had been proved correct, in relation to this species of freshwater forms. Of course, my theory assumes that the wider portions of these wedge-shaped segments contract, or, as it were, roll up upon themselves so as to form the nearly cylindrical tentacles as we know them. I place great weight upon the simultaneous appearance of the whole eight, without the slightest suggestion of longitudinal growth.

"The throbbings of the velum continued irregularly after the last drawing was made, finally liberating the medusa about 9 a. m. of the same day (May 18th). Two days had passed since the first determination of the bud, and the liberated medusa lived but two days longer, so that this specimen did not secure us any better sight of possible sense organs than had those seen ten years before." EDWARD PotTs.

\title{
MUTATION IN MICRO-ORGANISMS
}

Dobell (Jour. Genetics, Nov. I9I2 and Feb. I9I3) gives a valuable review of the literature and a summary of the conclusions of investigators concerning mutation in micro-organisms.

In Trypanosomes (Nov., I9I2,) it appears that definite structural changes may be produced by use of certain dyes, by cultivation in cold blooded vertebrates and certain invertebrates, which changes persist through subsequent divisions and apparently do not impair the power of division. In case of those treated with the dyes the kineto-nucleus is destroyed. The loss of this organ seems to decrease the virulence of the action of the Trypanosomes on the host. Virulence is changed also by the passage of the organism through the blood of certain animals. Resistance is developed by them also to certain drugs which are gradually administered. This increased resistance is transmitted in breeding.

In respect to the Bacteria, the author summarizes his digest in these words: "First it seems, established that the Bacteria are 
subject to mutation-that is to say, in a given race individuals may occur which differ from their fellows in their genetic constitution. Individuals frequently occur which possess new structural or functional features; and these features, though often the transient peculiarities of the individual only, are in some cases transmitted to the offspring for many successive generations. There is reason to suppose that this phenomenon occurs in nature as well as in laboratory cultures. The progeny of an organism which varies may thus constitute a new race, in which every individual possesses the new character."

The author defines mutation as a permanent change, however small it may be, which takes place in a micro-organism and is transmitted to subsequent generations. These mutations are classed as structural and physiological,- the latter comprising those in which the power of producing pigments, ferments, etc., is seen.

In some instances the mutations seem to be caused by chemical or other conditions of the medium; in others, in which effort was made to secure uniformity of medium, changes still occurred where it seems necessary to assume that the conditions of the changes were primarily internal.

\section{DIFFERENTIATION IN CHROMOSOMES}

Agar (Q. J. M. S. Dec. I9I2) reports studies of chromosomes in Lepidosiren in which he shows that there is a widespread tendency for chromosomes to be constricted or to segment transversely. This is especially noticeable when the chromosomes are short in comparison with their length. The point at which this constriction takes place in a given chromosome is constant for that chromosome, and is the point at which it most readily tends to form the angle of the $\mathrm{V}$ when that form is taken. The author believes that the constancy of this position denotes a constant differentiation of the chromosomes in the long axis. The presence of the constrictions is not, however, necessarily to be considered as evidence of bivalency or of a future division in that plane. 


\section{$2 \mathrm{BHL}$ Biodiversity Heritage Library}

1913. "Mutation in Micro-Organisms." Transactions 32, 151-152.

View This Item Online: $\underline{\text { https://www.biodiversitylibrary.org/item/84910 }}$

Permalink: https://www.biodiversitylibrary.org/partpdf/90788

\section{Holding Institution}

University of Toronto - Gerstein Science Information Centre

\section{Sponsored by}

University of Toronto

\section{Copyright \& Reuse}

Copyright Status: Not provided. Contact Holding Institution to verify copyright status.

This document was created from content at the Biodiversity Heritage Library, the world's largest open access digital library for biodiversity literature and archives. Visit BHL at https://www.biodiversitylibrary.org. 